\title{
SIMULATION APPROACHES FOR THE SOLUTION OF CRANKTRAIN VIBRATIONS
}

\section{PAVEL NOVOTNÝ, VÁCLAV PIÍTĚ̌K, LUBOMÍR DRÁPAL, ALEŠ PROKOP}

Institute of Automotive Engineering, Brno University of Technology, Technická 2896/2, 61669 Brno, Czech Republic Tel.: +420 541142 272, Fax: +420 541143 354, E-mail: novotny.pa@fme.vutbr.cz

\section{SHRNUTI}

Vývoj moderních pohonných jednotek vyžaduje využívání pokročilých výpočtových metod, nutných k požadovanému zkrácení času tohoto vývoje společně s minimalizací nákladů na něj. Moderní výpočtové modely jsou stále složitěǰši a umožnuji řešit mnoho různých fyzikálních problémů. $V$ prípadě dynamiky pohonných jednotek a životnosti jejich komponent lze využít několik různých prístupů. Prvním z nich je prístup zahrnující samostatné řešení každého subsystému pohonné jednotky. Druhý prístup využívá model pohonné jednotky obsahující všechny hlavní subsystémy, jako klikový mechanismus, ventilový rozvod, pohon rozvodů nebo vstriikovací čerpadlo, a řeší všechny tyto subsystémy současně i s jejich vzájemným ovlivněním. Cílem článku je pomocí vybraných výsledkủ prezentovat silné a slabé stránky obou přístupů. Výpočty a experimenty jsou prováděny na traktorovém vznětovém šestiválcovém motoru.

KLÍČOVÁ SLOVA: POHONNÁ JEDNOTKA, DYNAMIKA, VIBRACE, KLIKOVÝ MECHANISMUS, NVH, MKP

\section{ABSTRACT}

The development of modern powertrains requires the use of advanced CAE tools enabling a reduction in engine development times and costs. Modern computational models are becoming ever more complicated and enable integration of many physical problems. Concentrating on powertrain dynamics and component fatigue, a few basic approaches can be used to arrive at a solution. The first approach incorporates a separate dynamics solution of the powertrain parts. The second one solves a complete powertrain model including all significant parts, such as cranktrain, valvetrain, gear timing drive and injection pump. The paper deals with dynamics and fatigue analyses solved using different approaches. Computed and measured results relate to a tractor compression-ignition in-line six-cylinder engine.

KEYWORDS: POWERTRAIN, DYNAMICS, VIBRATION, CRANKTRAIN, NVH, FEM

\section{INTRODUCTION}

Modern internal combustion engine (ICE) powertrains are complex thermo-mechanical systems improved over time by large and gradual development. Powertrain producers are still managing to increase ICE performance together with achieving significant reductions in fuel consumption. In addition, low levels of noise, vibrations and exhaust emissions are required by the national legislative requirements of the world's markets. However, an increase in the engine performance often leads to an increase in the powertrain noise, vibration and harshness (NVH). Principally these problems can be solved by experimental or computational approaches. Experimental methods on ICE prototypes are time-consuming and quite expensive and therefore computational methods are increasingly being used. In the area of powertrain dynamics, experimental methods are often applied for computational model validations. This is because computational models can provide very exact results, but only on condition that accurate inputs are included. Therefore, the computational methods have a very important role, for example they enable the comparison of different design modifications without production of a prototype. There is a frequent and fundamental question asked in computational modelling: how complex should the models be for accurate solution of some level of given physical phenomena?

This contribution provides an answer regarding computational model complexity in the area of cranktrain dynamics and NVH. 


\section{STATE-OF-THE-ART IN}

\section{COMPUTATIONAL METHODS}

One of the many approaches can be represented by a computational model of the powertrain assembled in Multi-body Systems (MBS). This type of powertrain model, in other words a Virtual Engine or Virtual Powertrain, is solved in the time domain. This fact enables different physical problems including various non-linearities to be incorporated. In the case of this paper, the virtual engine is assembled as well as numerically solved in MBS ADAMS. ADAMS is a general code and enables integration of user-defined models to be made directly using ADAMS commands or user-written FORTRAN or $\mathrm{C}++$ subroutines [2].

In general, the virtual engine includes all significant components necessary for noise, vibration and harshness (NVH) or fatigue analyses. The virtual engine can include different modules, such as a cranktrain, a valvetrain, a gear timing drive with fuel injection pump, a balancing unit, a rubber damper and other submodules. The following analyses are focused on the cranktrain as a central module of the virtual engine.

The cranktrain modules of different levels consist of solid model bodies, linearly elastic model bodies and interaction models between them.

The solid model bodies for all types of cranktrain module are:

- Piston assembly,

- Connecting rod assembly,

- Crankshaft pulley,

- Additional flywheel mass,

- Dynamometer rotor.

The linearly elastic model bodies are Finite Element (FE) models modally reduced using the Craig-Bampton method. These are:

- Crankshaft,

- Engine block.

A dumb-bell shaft connecting a flywheel with a dynamometer rotor is represented by a body with defined torsional stiffness and damping. These characteristics are adjusted on account of torsional vibration measurements.

Some subsystems having an indispensable influence on cranktrain vibrations are modelled by their inertia characteristics or power requirement with corresponding speed ratio (the valvetrain, balancing shafts, and injection unit).

The interaction between the crankshaft and the engine block is ensured via a non-linear hydrodynamic journal bearing model, where pre-calculated force databases obtained when solving a separate hydrodynamic problem are used.

The virtual engine is excited by means of cylinder pressure defined by high-pressure measurement, and via inertial forces from moving parts.

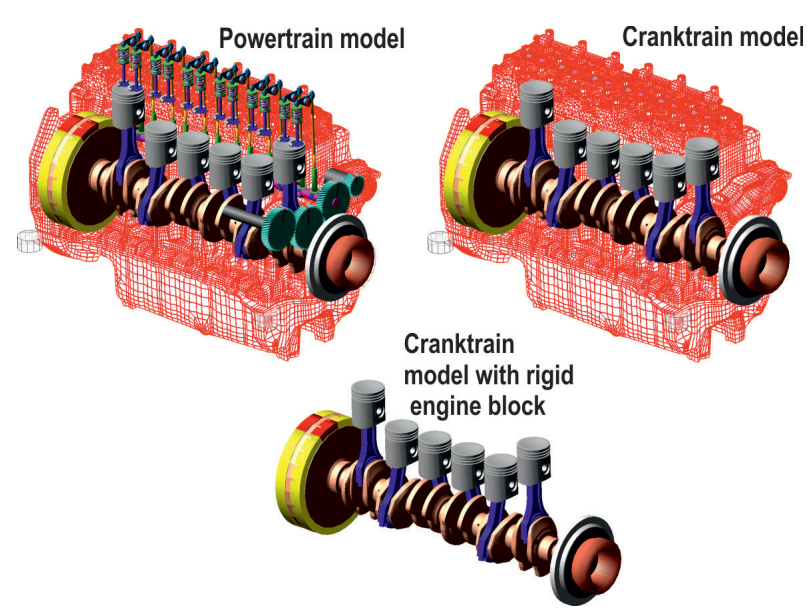

FIGURE 1: Cranktrain computational models OBRÁZEK 1: Výpočtové modely klikového mechanismu
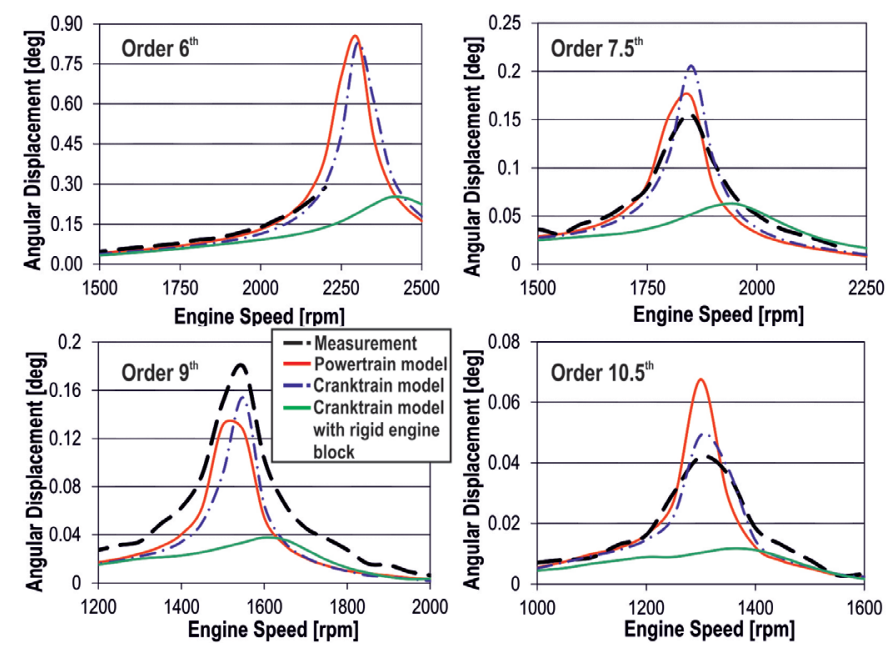

FIGURE 2: Harmonic analyses of crankshaft pulley torsional vibrations without torsional damper for different computational models OBRÁzEK 2: Harmonická analýza torzních vibrací řemenice klikového hř́dele bez tlumiče torzních kmitů

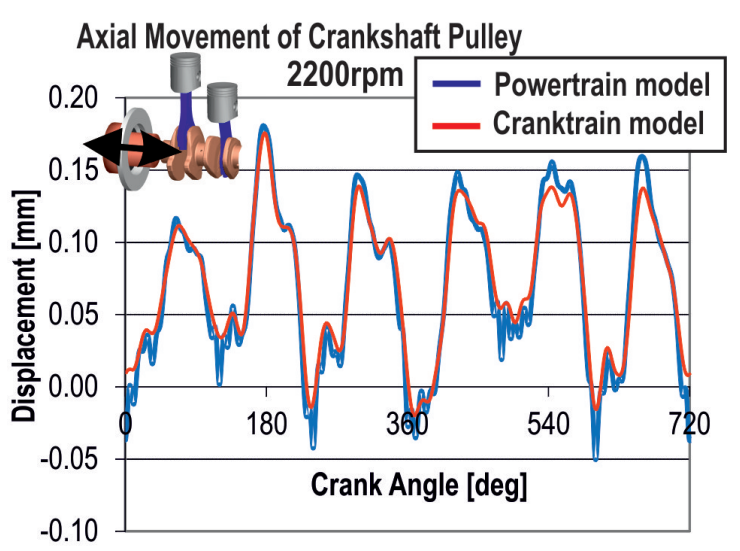

FIGURE 3: Crankshaft pulley axial movement relative to the engine block for engine speed 2200 rpm, cranktrain without damper OBRÁZEK 3: Axiální pohyb řemenice klikového hřídele vzhledem k bloku motoru pro otáčky motoru 2200 min $^{-1}$, klikový mechanismus bez tlumiče 


\section{COMPARISONS OF CRANKTRAIN \\ COMPUTATIONAL MODELS}

Cranktrain computational models of different levels can be used for cranktrain dynamic solutions. To date the cranktrain dynamics have often been solved using an independent cranktrain model with or without flexible bodies. Flexible bodies have mostly been reduced FE models. The following cranktrain computational models are used for comparisons:

- A powertrain model including a cranktrain, a valvetrain, a timing gear mechanism and an injection pump. The main components are modelled as flexible structures incorporating reduced FE models (a crankshaft, an engine block, a camshaft, rockers and valve springs).

- An independent cranktrain model incorporating reduced FE models of a crankshaft and an engine block.

- An independent cranktrain model with a rigid engine block model incorporating a reduced FE model of a crankshaft.

Independent cranktrain models include the crankshaft with an additional body located in the crankshaft front end. An inertia moment of the additional body is equivalent to inertia moments of meshing timing gears and the camshaft. The cranktrain computational models are presented in Figure 1.

In computational modelling time is one of the requirements necessary for solving the models. The computational time of course depends on the type of computer used. To find computational time cost, one can compare CPU times for different computational models solving the cranktrain dynamics including the solution of six engine cycles for an engine speed of $2200 \mathrm{rpm}$. The computational time for a solution of the powertrain model takes 153 minutes, the cranktrain model is solved in 61 minutes and the cranktrain model with a rigid engine block is solved in only 4 minutes. The maximum integration time step is restricted by the value $1 \times 10^{-5} \mathrm{~S}$. A PC (Personal Computer) including Intel Pentium $3 \mathrm{GHz}$ Quad-core CPU and 16 GB RAM with Windows 7 64bit operating system was used for cranktrain computational model solutions.

In particular, reduced FE models significantly increase CPU times needed for computational model solutions. A large number of contacts between valvetrain parts also increases CPU times. CPU times are an important factor to take into account when considering computational model levels.

Important results from cranktrain computational models are torsional vibrations of the crankshaft pulley. Figure 2 compares the results of the chosen cranktrain computational models and measurements (without a torsional damper). Only the chosen harmonic orders resonating in the operating speed range of the target engine are presented.
The powertrain model and the independent cranktrain model incorporating reduced FE models of a crankshaft and an engine block agree relatively well with the measurements. Graphical representations are influenced by high engine speed steps for measurements and computations. The independent cranktrain model with a rigid engine block model gives inaccurate results and cannot be recommended for cranktrain dynamic solutions in the case of the target engine.

Crankshaft axial movements, mainly those of a crankshaft pulley, are partially influenced by the gear timing mechanism. Independent cranktrain models on principle cannot show these influences. Comparisons of crankshaft pulley movements of the powertrain and the independent cranktrain models are presented in Figure 3.

Figure 4 compares selected results of main bearings No. 4 and No. 7 for different computational models. Maximum relative eccentricities in the main bearing No. 4 reach a value of 0.904 for an engine speed of $2200 \mathrm{rpm}$.

Comparisons of bearing results show a relatively good correspondence between the powertrain model and the independent cranktrain model, except for the axial crankshaft movements and axial bearing results for the radial-axial main bearing No. 7 . The result differences are caused by the gear timing mechanism located on the front end of the crankshaft because the gear timing drive includes helical gears. The independent cranktrain model with a rigid engine block model gives very different results again.

Cranktrain model types also influence computed normal velocities on engine block surfaces. The normal velocities of the
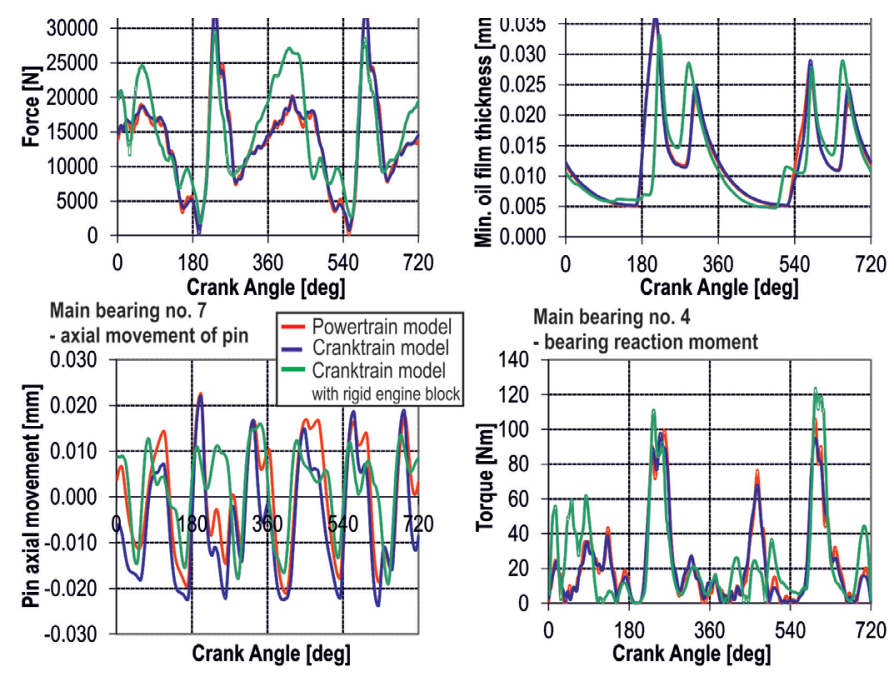

FIGURE 4: Comparisons of selected main bearing results for different computational models for engine speed $2200 \mathrm{rpm}$, radial and axial bearing clearances $0.1 \mathrm{~mm}$

OBRÁzEK 4: Porovnání vybraných výsledků kluzných ložisek pro různé varianty výpočtového modelu klikového mechanismu při otáčkách motoru $2200 \mathrm{~min}^{-1}$, radiální a axiální vưle ložiska $0.1 \mathrm{~mm}$ 


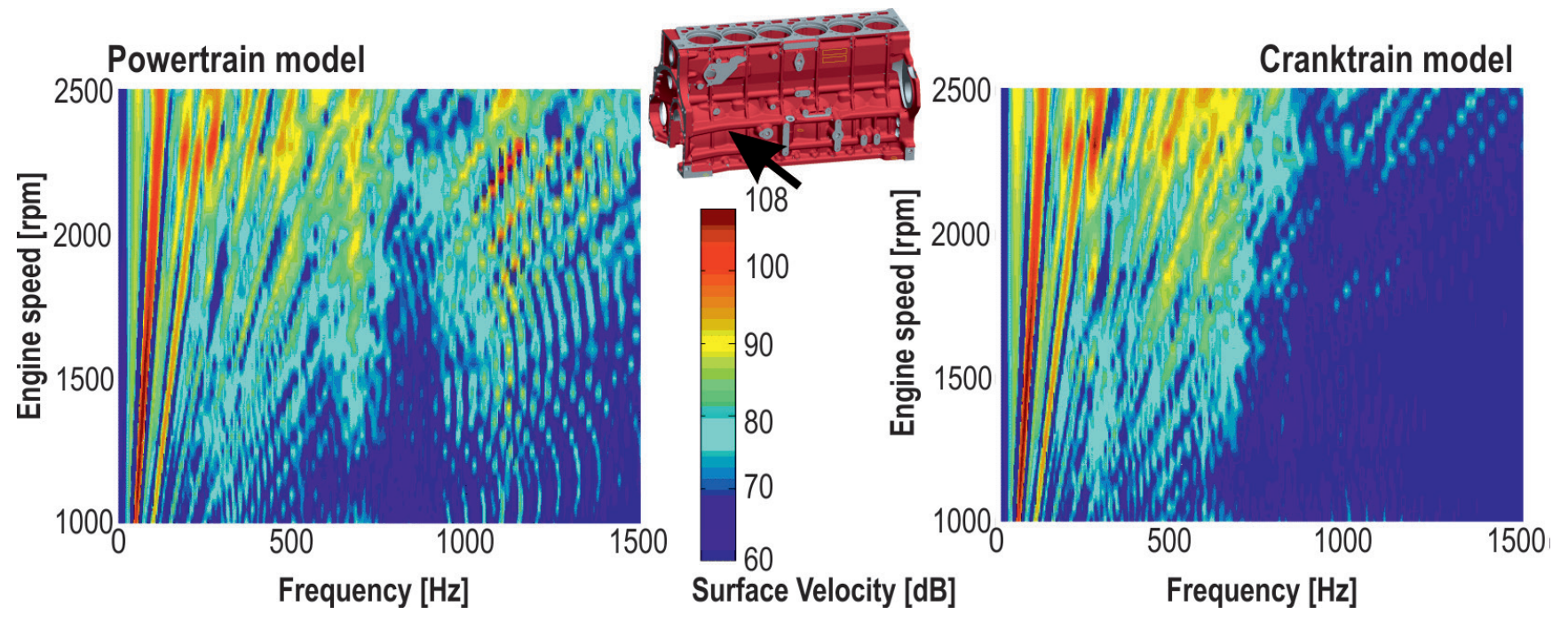

FIGURE 5: Campbell diagram of normal velocity of the crankcase surface

OBRÁZEK 5: Campbellův diagram normálové rychlosti na povrchu klikové skříně
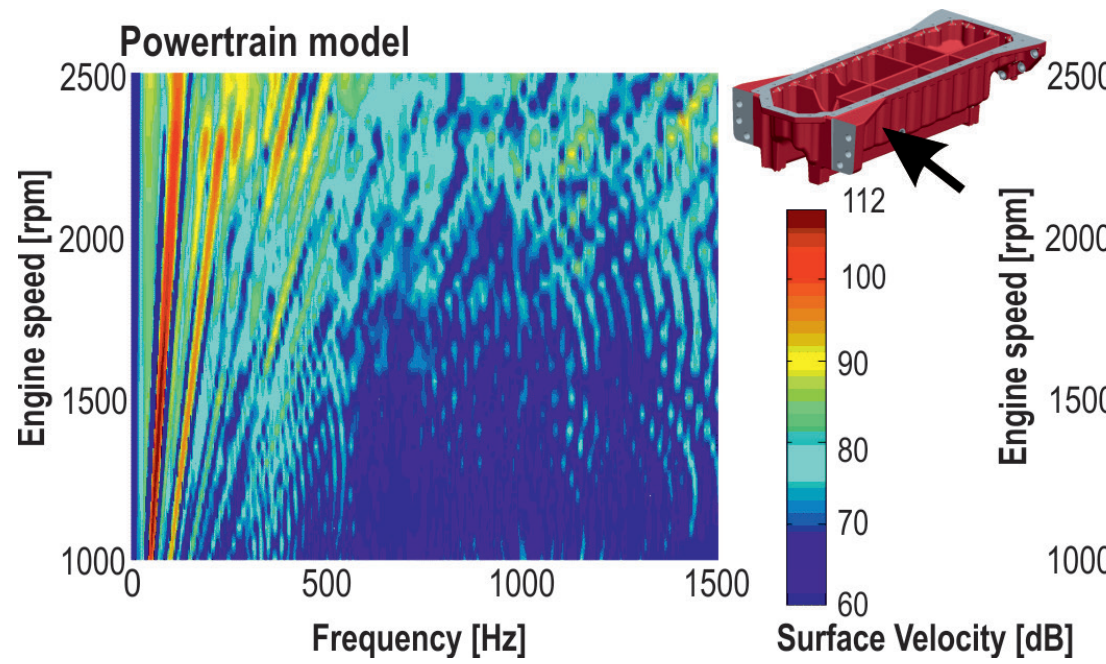

FIGURE 6: Campbell diagram of normal velocity of the bottom engine cover surface

OBRÁZEK 6: Campbellův diagram normálové rychlosti na povrchu spodního víka motoru

engine block surface significantly influence acoustic emissions produced by a powertrain. Figure 5 presents Campbell diagrams of a normal velocity of a crankcase surface near the first cylinder and a crankshaft axis. Figure 6 presents the Campbell diagram of a normal velocity of the bottom engine cover surface (an oil sump) near the second cylinder. A value of $5 \times 10^{-8} \mathrm{~ms}^{-1}$ is taken as a reference velocity for the Campbell diagrams.

Campbell diagrams confirm previous results and in the case of the powertrain computational model show an increase of vibration levels in the frequency range $900-1400 \mathrm{~Hz}$, mainly for high engine speeds. These vibrations are influenced by the gear timing drive and the injection pump torque. The incorporation of these influences leads to a more accurate solution of vibrations and noise produced by a powertrain.

\section{CONCLUSIONS}

The results of the work show that the most accurate computational models for the solution of noise, vibration and component fatigue questions are the complex powertrain models. These models also enable the understanding of interactions between different powertrain subsystems. The fact that all results are computed by one computational model and stored in one result file is also an advantage.

The biggest disadvantage is the high model complexity. The complex computational models require a high number of parameters to be inputted, which are often difficult to obtain. Other disadvantages are the long solution times to solve the models numerically and sometimes the large storage space required for the computed results. 
In the case of the cranktrain model it is evident that a computational model of an engine block can significantly influence the results in the areas of dynamics of the main parts or component fatigues. This is the reason for incorporation of some flexibility into the engine block model. One of the simplest ways to incorporate flexibility is to include springs and dampers arranged in parallel for each main bearing and engine block interface. The stiffness can be found by a separate FE solution of the engine block model. This engine block computational model does not significantly influence cranktrain solution times, and sometimes it can provide reasonable results. The Impossibilities of engine block dynamic solutions or difficulties in damping value estimations are the main disadvantages.

More precise computational models of an engine block are full flexible models incorporating reduced FE models. In the case of a correct reduction, these models enable inclusion of stiffness and damping of all engine block parts. Engine block dynamics, noise and vibration questions can be also solved by these computational models. The determination of engine block surface velocities and use of these velocities for powertrain noise estimations can be taken as an example.

The comparison of cranktrain computational model results incorporating a reduced FE model of an engine block with experiments shows that the cranktrain is not significantly influenced by other powertrain subsystems when a global cranktrain dynamics solution is required. This is caused by large inertia moments of cranktrain parts in comparison with the gear timing drive or the valvetrain.

\section{ACKNOWLED GEMENTS}

This research has been realized using the support of Technology Agency of the Czech Republic, programme Centres of Competence, project no. TE01020020 Josef Božek Competence Centre for Automotive Industry and with the help the Ministry of Education, Youth and Sports, project NETME Centre New Technologies for Mechanical Engineering and project reg. No. CZ.1.05/2.1.00/01.0002. This support is gratefully acknowledged.

\section{LIST OF ABBREVIATIONS}

$\begin{array}{ll}\text { ADAMS } & \text { Commercial software for MBS } \\ \text { CAE } & \text { Computer Aided Engineering } \\ \text { CPU } & \text { Central Power Unit } \\ \text { FE } & \text { Finite Element } \\ \text { FEM } & \text { Finite Element Method } \\ \text { FORTRAN } & \text { Programing language software } \\ \text { ICE } & \text { Internal Combustion Engine } \\ \text { MBS } & \text { Multi-Body System } \\ \text { NVH } & \text { Noise Vibration and Harshness } \\ \text { PC } & \text { Personal Computer }\end{array}$

\section{REFERENCES}

[1] NOVOTNÝ P. (2009). Virtual Engine - A Tool for Powertrain Development, Inaugural Dissertation, Brno University of Technology.

[2] DRÁPAL L., NOVOTNÝ P., PÍŠTĚK V., AMBRÓZ R. (2011). Virtual engine application for powertrain dynamics, XLII. International Scientific Conference of Czech and Slovak University Departments and Institutions dealing with the Research of Combustion Engines, Žilina, Slovak Republic.

[3] DRÁPAL L., NOVOTNÝ P., PÍŠTĚK V. (2012). Modelling Approaches for a Solution of Powertrain Dynamics, Fatigue and NVH, XLIII. International Scientific Conference of the Czech and Slovak University Departments and Institutions Dealing with the Research of Internal Combustion Engines, Roztoky, Czech Republic. 